\title{
SOIL BIOLOGICAL ACTIVITY UNDER THE HUMAN-INDUCED IMPACT IN THE FARMED ECOSYSTEM
}

\author{
Olena Litvinova $^{1}$, Dmytro Litvinov ${ }^{1 *}$, Svitlana Romanova ${ }^{2}$, Svitlana Kovalyova $^{3}$ \\ ${ }^{1}$ National university of life and environmental sciences of Ukraine. Heroiv Oborony str., 12, bulding 7, Kyiv, 03041, \\ Ukraine; \\ ${ }^{2}$ State Institution «Soils Protection Institute of Ukraine», Babushkina Per., 3, Kyiv, 03190, Ukraine; \\ ${ }^{3}$ Zhytomyr Branch State Institution «Soils Protection Institute of Ukraine». Prospect Mira, 21 A, Zhytomyr, 10020, \\ Ukraine; \\ *Corresponding author Dmytro Litvinov, e-mail: litvinovdv2018@ukr.net;
}

Received June 2019; Accepted July 2019; Published August 2019;

DOI: https://doi.org/10.31407/ijees9316

\begin{abstract}
The application of organic fertilizers (60 t/ha of dung) to gray forest soils increases the proportion of deeply humified humus substances within a humus, so the soils become more cultured. The organic-mineral fertilizer system (12 t of dung and $220 \mathrm{~kg}$ of NPK - nitrogen-phosphorus-potassium - per 1 ha of crop rotation area) and the organic fertilizer system ( $24 \mathrm{t} / \mathrm{ha}$ of dung) result in humus wide reproduction at the level of 1,32\% and 1,35\% comparing to the initial level $(1,20 \%)$. The regular input of fresh organic fertilizers into soil caused the 1,5-times increase of intensity of biological processes (according to $\mathrm{CO}_{2}$ release) if compared to the soil without such an input. The intensity of $\mathrm{CO} 2$ release rose by $56 \%$ while applying organic-mineral fertilizers, by $28 \%$ with organic fertilizers, and by $14 \%$ with mineral fertilizers if compared to the control soil without applying fertilizers (118 $\mathrm{mg}$ of carbon-dioxide per $1 \mathrm{sq} . \mathrm{m} . / \mathrm{h}$ ). The input of organic fertilizers in soil changed the concentration of microorganisms which decompose cellulose, and they prove to be rather good indicators of changes of soil agronomical properties. The cellulose-decomposing activity of soil nourished only with mineral fertilizers was $38,9 \%$, that is a medium intensity. The cellulose-decomposing activity of soil amended only with fresh organic fertilizers rose to $80 \%$ that corresponded to a strong intensity. Fertilizing with both organic and mineral material stimulated the process of cellulose decomposing up to $82,4 \%$. The intensity of a nitrification process reflects a potential soil biological activity. According to the research, the low nitrification intensity was observed in soil without fertilization $(12,8$ $\mathrm{mg} / \mathrm{kg}$ ), while the nitrification intensity rose to $14,0 \mathrm{mg} / \mathrm{kg}$ after mineral fertilization and to $17,4 \mathrm{mg} / \mathrm{kg}$ after organic fertilization. We revealed that the nitrification ability of soil tended to increase up to $21,9 \mathrm{mg} / \mathrm{kg}$ following the combined application of organic and mineral fertilizers, consequently coordinating with cellulose-decomposing activity changes of soil microbial cenosis under field conditions.
\end{abstract}

Key words: soil biological activity, humus, fertilization, soil fertility, fertilizers 